\title{
The Killdeer Site (41SM379): A Middle Caddo Site in Northern Smith County, Texas
}

Timothy K. Perttula

Heritage Research Center, Stephen F. Austin State University

Mark Walters

Heritage Research Center, Stephen F. Austin State University

Follow this and additional works at: https://scholarworks.sfasu.edu/ita

Part of the American Material Culture Commons, Archaeological Anthropology Commons, Environmental Studies Commons, Other American Studies Commons, Other Arts and Humanities Commons, Other History of Art, Architecture, and Archaeology Commons, and the United States History Commons

Tell us how this article helped you.

This Article is brought to you for free and open access by the Center for Regional Heritage Research at SFA ScholarWorks. It has been accepted for inclusion in Index of Texas Archaeology: Open Access Gray Literature from the Lone Star State by an authorized editor of SFA ScholarWorks. For more information, please contact cdsscholarworks@sfasu.edu. 


\section{The Killdeer Site (41SM379): A Middle Caddo Site in Northern Smith County,}

Texas

\section{Creative Commons License}

\section{(c) (1) (8)}

This work is licensed under a Creative Commons Attribution-NonCommercial 4.0 International License 


\title{
The Killdeer Site (41SM379): A Middle Caddo Site in Northern Smith County, Texas
}

\author{
Timothy K. Perttula and Mark Walters
}

\section{INTRODUCTION}

The Killdeer site was reported in July 2007 by Mark Walters, based on a surface reconnaissance of the site area and a small surlace collection of artifacts, primarily prehistoric Caddo pottcry sherds. The site is situated on a lower upland slope (410 feet amsl) about $190 \mathrm{~m}$ northeast of Loves Branch, a small stream in the Harris Creek drainage in the Sabine River basin. Soils are a Redsprings very gravelly sandy loam, $8-25 \%$ slopes. Darkly-stained sediments and burned animal bone suggest that there is a Caddo midden deposit at the northern end of the site.

\section{Artifacts}

The artifacts $(n=119)$ collected from the Killdeer site include 75 Caddo ceramic sherds, a piece of burned clay, one burned animal bone, one Gary dart point, two expedient flake tools, one chipped adze, 36 pieces of lithic debris, a ground stone mano, and one piece of quartzite firc-cracked rock.

\section{Ceramic Sherds}

The sherds from the Killdeer site include 46 plain sherds and 29 decorated sherds. The plain to decorated sherd ratio is 1.59 , which is indicative of the latter part of the Middle Caddo age in this part of the upper Sabine River basin. The plain sherds are represented by one rim, 44 body, and one base. Only $2 \%$ of the plain sherds are from vessels tempered with crushed and burned bone; rather, the sherds are from grog-tempered vessels.

The decoratcd sherds from the site are dominated by sherds from utility ware vessels, probably conking jars (Table 1). Approximately $90 \%$ of the decorated sheds are from utility wares, and only $10 \%$ are from fine ware bowls and carinated bowls. Only $3.5 \%$ of the decorated sherds are from bone-lempered vessels; the vast majority of the sherds are tempered with grog.

'The principal utility wares have brushed (52\% of the decorated sherds), brushed-incised $(3.4 \%)$, and brushed-punctated $(10.3 \%)$ decorations; $65.7 \%$ of the decorated sherds from the Killdeer site have brushed decorations. These sherds are probably from Bullard Brushed vessels. Other utility wares have appliqued $(3.4 \%)$, incised $(13.8 \%)$, and punctated $(6.9 \%)$ decorative elements. One of the incised body sheds has a vertical and opposed incised decorative element that occurs with regularity on Pease Brushed-Incised vessels (Suhm and Jelks 1962:Plate 60k).

As previously mentioned, sherds from fine ware vessels are not common in the decorated sherd assemblage from the site, accounting for only $10 \%$ of the assemblage (see Table 1). The fine ware sherds include two body sherds with single straight engraved lines as well as a bowl or carinated bowl body sherd with a red slip on both interior and exterior vessel surfaces. Generally speaking, red-slipped sherds are only common in upper Sabine River Caddo sites that were occupied during the Middle Caddo period (Perttula 2011a, 2011b). 
Table 1. Decorated sherds from the Killdeer Site (41SM379).

\begin{tabular}{|c|c|c|c|}
\hline Decorative element & Rim & Body & $\%$ Bone-tempered \\
\hline \multicolumn{4}{|l|}{ Utility Ware } \\
\hline straight appliqued ridge & - & 1 & 0.0 \\
\hline opposed brushed & - & 2 & 0.0 \\
\hline parallel brushed & - & 13 & 7.7 \\
\hline parallel brushed-incised & - & 1 & 0.0 \\
\hline $\begin{array}{l}\text { horizontal brushed with } \\
\text { tool punctates thru the } \\
\text { brushing }\end{array}$ & 1 & - & 0.0 \\
\hline $\begin{array}{l}\text { parallel brushed with } \\
\text { tool punctates thru the } \\
\text { brushing }\end{array}$ & - & 2 & 0.0 \\
\hline $\begin{array}{l}\text { vertical and opposed } \\
\text { incised lines }\end{array}$ & - & 1 & 0.0 \\
\hline opposed incised lines & - & 1 & 0.0 \\
\hline parallel incised lines & - & 1 & 0.0 \\
\hline straight incised lines & - & 1 & 0.0 \\
\hline cane punctated rows & 1 & - & 0.0 \\
\hline fingernail punctated rows & 1 & - & 0.0 \\
\hline \multicolumn{4}{|l|}{ Fine Ware } \\
\hline straight engraved lines & - & 2 & 0.0 \\
\hline int./ext. red-slipped & - & 1 & 0.0 \\
\hline Totals & 3 & 26 & 3.5 \\
\hline
\end{tabular}

\section{Chipped Stone Tools and Lithic Debris}

The one dart point in the collection is a narrow contracting stem Gary point, var. Camden, inadc from a local quartzite. The var. Cainden is a latc Woodland dart point form, estimated by Schambach (1982) to date from ca.A.D. 200-700. There are also two expedient flake tools, probably used for cutting and scraping tasks, made from chert, and a bifacial adze made from a local quartzite.

The lithic debris includes chert ( $\mathrm{n}=31,6.4 \%$ cortical), petrified wood $(n=4,75 \%$ cortical), and quartzite $(\mathrm{n}=1,0 \%$ cortical, heat-treated); its presence at the site indicates that tools were made and refurbished there during at least one of the occupations. The petrified wood and quartzite raw materials are considered to be locally available, probably in stream gravels along the major streams, most likely the Sabine River. The chert debris are probably from non-local sources (given the low proportion of cortical flakes), and is a product of the refurbishing, maintenance, and resharpening of already completed chert tools that were brought to the site. 


\section{Ground Stone Tool}

The one ground stone tool is a ferruginous sandstone mano-pitted stone. Both surfaces of the cobble have smoothed grinding areas as wcll as pitted areas in the central part of the tool.

\section{SUMMARY AND CONCLUSIONS}

The Killdeer site is one of many Middlc Caddo habitation sites on tributaries to the Sabine River in this part of the Upper Sabine River basin (Pertula et al. 1993; Pertula and Walters 2012; Walters 2003, 2006. 2008; Walters and Haskins 1998, 2000; Walters and Perttula 2011); it also has a Woodland period component that likely dates from ca. A.D. 200-700. The Middle Caddo component at the Killdeer site is marked by a ccramic assemblage dominated by sherds from utility ware vesscls (probably cooking jars) decorated with brushing, incised lines, punctated clcments, and appliqued ridges, and a low percentage of engraved and red-slipped fine wares. Sherds from vessels with brushcd decorations are by far the most common in the small decorated sherd assemblage; this, combined with a plain to decorated sherd ratio of 1.59 , suggcsts that the Killdeer site was likely occupied by a Caddo group in the latter part of the Middle Caddo period, after ca. A.D. 1300.

\section{REFERENCES CITED}

Perttula, T. K.

201 la Analysis of the Prehistoric Artifacts from the Pace McDonald Site (41AN51), Anderson County, Texas. Journal of Northeast Texas Archaeology 34:35-54.

2011b The Ceramic Artifacts from the Lang Pasture Site (41AN38) and the Place of the Site within an Upper Neches River Basin Caddo Ceramic Tradition. In Archeological Investigations at the Lang Pasture Site (4IAN38) in the Upper Neches River Basin of East Texas, assembled and edited by T. K. Perttula, D. B. Kelley, and R. A. Ricklis, pp. 145-320. Archeological Studics Program Report No. 129, Texas Department of Transportation, Environmental Affairs Division, Austin.

Perltula, T. K. and M. Walters

2012 Caddo Sites in the Saline Creek Basin in Northern Smith County, Tcxas. Journal of Northeast Texas Archaeology 36:47-63.

Perttula, T. K., B. D. Skiles, and B. C. Yates

1993 The Carlisle Site (4IWD46), a Middle Caddoan Occupation on the Sabine River, Wood County, Texas. Notes on Northeast Texas Archaeology 1:34-62.

Schambach, F. F.

1982 An Outline of Fourche Malinc Culture in Southwest Arkansas. In Arkansas Archeology in Review, edited by N. L. Trubowitz and M. D. Jeter, pp. 132-197. Research Series No. 15. Arkansas Archeological Survey, Hayctteville.

Suhm, D. A. and E. B. Jelks (editors)

1962 Handbook of Texas Archeology: Type Descriptions. Special Publication No. 1, Texas Archeological Society, and Bulletin No. 4, Texas Memorial Museum, Austin. Reprinted in 2009, Gustav's Library, Davenport, lowa. 
Walters, M.

2003 The Wolf Site (41SM195), Smith County, Texas. Journal of Northeast Texas Archaeology 18:1-21.

2006 The Lake Clear (41SM243) Site and Crotalus horridus atricaudatus. Caddoan Archeology Journal 15:5-41.

Walters, M., with contributions from L. G. Cecil, L. S. Cummings, J. P. Dering, J. R. Ferguson, M. D. Glascock, T. K. Perttula, L. Schniebs, H. J. Shafer, J. Todd, and C. P. Walker

2008 Life on Jackson Creek, Smith County, Texas: Archeological Investigations of a $14^{\text {th }}$ Century Caddo Domicile at the Leaning Rock Site (41SM325). Caddo Archeology Journal 17:1-114.

Walters, M., and P. Haskins

1998 Archaeological 1nvestigations at the Redwine Site (41SM193), Smith County, Texas. Journal of Northeast Texas Archaeology 11:1-38.

2000 The Bryan Hardy Site (41SM55), Smith County, Texas. Journat of Northeast Texas Archaeology 12:1-26.

Walters, M. and T. K. Perttula

2011 New Radiocarbon Dates from Two Caddo Mound Centers in East Texas. Texas Archeology (Newsletter of the Texas Archeological Society) 55(2):14-16. 